\title{
Function of Deubiquitinating Enzyme USP14 as Oncogene in Different Types of Cancer
}

\author{
Ying Zhu ${ }^{\mathrm{a}}$ Chaoxiong Zhang ${ }^{\mathrm{b}}$ Changxin Guc ${ }^{\mathrm{c}}$ Qiang Lia Ning Wu \\ aDepartment of Respiratory Medicine, Changhai Hospital, Second Military Medical University, Shanghai, \\ ${ }^{b}$ Department of Centre for Disease Prevention and Control, Chengdu Military Region, Chengdu, \\ 'Shanghai airport authority, Shanghai, China
}

\section{Key Words}

USP14 • Cancers • Prognosis • Proliferation • Survival • Apoptosis • Migration

\begin{abstract}
Background/Aims: Non-small cell lung cancer (NSCLC) tissues overexpress USP14, which promotes tumor cell proliferation and is associated with shorter overall survival time. Methods: The expression of USP14 was assayed in many types of cancers. USP14 was up-and down-regulated using appropriate plasmid or lentiviral vector constructs and its effects on proliferation, cell colony number, and apoptosis rate were measured. A human NSCLC cell line was inoculated into nude mice and the survival rates were recorded. Results: We found USP14 amplification and overexpression in many different cancers. The overexpression of USP14 in USP14 low-expression cell lines promoted cell proliferation and migration, whereas USP14 downregulation suppressed tumor cell proliferation, decreased tumor cell colony number, increased apoptosis rate, and decreased cell migration and invasion. Conclusion: USP14 plays an oncogenic role in various types of cancer, and may thus represent a new cancer therapy target.
\end{abstract}

Copyright (c) 2016 S. Karger AG, Basel

\section{Introduction}

Deubiquitinating enzymes (DUBs) remove covalently attached ubiquitin from proteins, thereby controlling substrate activity and/or abundance [1]. The USP family of DUBs, specifically, plays a crucial role in various cellular processes and signaling pathways [2-11]. Mammalian proteasomes are associated with three DUBs: RPN11, UCH37, and USP14 [2, 4]. USP14, in particular, can inhibit proteasomes in vitro as well as protein turnover in cells [2].

Y. Zhu, C. Zhang, C. Gu contributed equally to this work.

Qiang Li and Ning Wu

KARGER
Department of Respiratory Medicine, Changhai Hospital, Second Military Medical University, Shanghai 200433, (China)

Fax+862181871114, E-Mail qiangli20122012@126.com, E-Mail wnrainbow@126.com 


\begin{tabular}{|c|c|c|}
\hline Cellular Physiology & Cell Physiol Biochem 2016;38:993-1002 & \\
\hline and Biochemistry & $\begin{array}{l}\text { DOI: 10.1159/000443051 } \\
\text { Published online: March 04, } 2016 \\
\end{array}$ & $\begin{array}{l}\text { O } 2016 \text { S. Karger AG, Basel } \\
\text { www.karger.com/cpb }\end{array}$ \\
\hline
\end{tabular}

We demonstrated in a previous study that USP14 is up-regulated in NSCLC tumor tissues, and as such is associated with shorter patient survival times [12]. To the best of our knowledge, our report was the first to show that USP14 plays a role in NSCLC.

The exact mechanisms through which USP14 affects NSCLC and other types of cancer are unknown, however all cancers result from the accumulation of genetic changes that occur in the DNA sequence of the genomes of cancer cells, so in order to create a compendium of genetic changes in specific cancers, it is important to obtain the complete DNA sequence of large numbers of cancer genomes. The Cancer Genome Atlas (TCGA) project is a large-scale collaborative effort to characterize the genomic changes inherent to cancer; the TCGA has profiled and analyzed rather large numbers of human tumors in order to catalog molecular aberrations at DNA, RNA, protein, and epigenetic levels. The TCGA data allows us to build an integrated understanding of commonalities, differences, and emergent themes across tumor lineages [13].

We investigated the role of USP14 in various types of cancer in this study. Based on a search through the TCGA database, we first analyzed the oncogenic role of USP14 in different types of cancer and found that its up-or down-regulation affects cell proliferation and apoptosis an array of cancer cell lines. The results of this study altogether indicate a possible oncogenic role of USP14.

\section{Materials and Methods}

\section{Cell Culture}

Human Embryonic Kidney 293 cells HEK293T, human normal lung fibroblast cell line MRC-5, human NSCLC cell lines (SK-MES-1, H1299, SPC-A-1, LTEP-A-2 and A549), human breast cancer cell lines (MCF10A, MCF-7, MDA-231), hepatic cell line L02, human hepatocarcinoma cell lines (HepG2, Huh-7), human glioma cell lines (U251), human pancreatic carcinoma cell line (PANC, SW1990), human prostate cancer cell lines (DU145, PC3), and human gastric adenocarcinoma cell lines (AGS, MKN45) were purchased from the American Type Culture Collection (ATCC) and cultured in either Dulbecco's modified eagle medium (DMEM) or 1640 medium (Hyclone, South Logan, UT, USA) supplemented with 10\% fetal bovine serum (Hyclone), 2 mM L-glutamine, and $100 \mu \mathrm{g} / \mathrm{mL}$ penicillin/streptomycin (Bio Light, Shanghai, China) as described in our previously published study [12].

\section{Mice and Treatment}

Nude mice were obtained from the Animal Center of the Chinese Academy of Science (Shanghai, China), and maintained in the Mice Care Center of the Second Military Medical University. A549 cells were inoculated into nude mice subcutaneously at a density of 1 x $10^{7}$ cell/ml and volume of $100 \mathrm{ml}$. After A549 cell inoculation, all mice were carefully monitored and their tumor volumes were measured every week. The survival rates of the nude mice were recorded during a 160-day follow-up period.

USP14 Amplification and Expression in Different Types of Cancer

USP14 amplification data and graph were obtained from the cBioPortal for Cancer Genomics [14, 15]. The USP14 expression in tumor data came from the Gene Expression Omnibus (GEO) (http://www.ncbi. nlm.nih.gov/geo/).

\section{Immunohistochemistry Analysis}

We obtained 45 LC tissues, 60 BC tissues, and 37 PDAC tissues from Changhai Hospital, Second Military Medical University (Shanghai, China). All patients provided signed, informed consent for their tissues to be used for scientific research. The Ethical Committee of Changhai Hospital, Second Military Medical University (Shanghai, China) approved our procedures. All diagnoses were based on pathological and/or cytological evidence. The histological features of the specimens were evaluated by senior pathologists according to the World Health Organization classification criteria. Tissues were obtained before chemotherapy and radiotherapy and immediately frozen and stored at $-80^{\circ} \mathrm{C}$. Immunohistochemistry images were analyzed in Image Pro-plus.

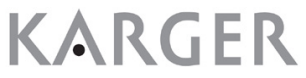




\section{Cellular Physiology Cell Physiol Biochem 2016;38:993-1002 \begin{tabular}{ll|l} 
DOI: 10.1159/000443051 & $\begin{array}{l}\text { O 2016 S. Karger AG, Basel } \\
\text { www.karger.com/cpb }\end{array}$ \\
\hline and Biochemistry &
\end{tabular}}

RNA Extraction and Real-time qPCR

We extracted RNA with Trizol reagent (Invitrogen, Carlsbad, CA, USA) according to the manufacturer's protocol, then performed cDNA synthesis and real-time qPCR using the Qiagen system [12]. Real-time quantitative PCR analysis was performed using standard protocols on an Applied Biosystem's 7500 HT sequence Detection System, and primer design was based on standard protocols [16] as synthesized by Shengong Company (Shanghai, China).

\section{Plasmid Transfection}

USP14 overexpression plasmids (Plasmid 22569: Flag-HA-USP14) [1] were constructed by Shengong Company (Shanghai, China). Flag-HA-USP14 were transfected into cells $\left(6 \times 10^{4}\right.$ cells/ well) using Lipofectamine 2000 (Invitrogen, Carlsbad, CA, USA), then collected after 48h for confirmation and further assay.

\section{Lentivirus Vectors}

The USP14 lentivirus vectors and scramble control ( $\mathrm{Src}$ ) were generated by Shengong Company (Shanghai, China). Cells were transfected with $1 \mathrm{~mL}$ of lentiviral supernatant containing equal doses $(4 \times$ $10^{8} \mathrm{PFU}$ ) for $2 \mathrm{~h}$ at a multiplicity of infection of $1: 5$, followed by incubation for $2 \mathrm{~h}$ at $37^{\circ} \mathrm{C}$ according to previously published methods $[12,17,18]$. Gene transfer efficiency was evaluated by GFP expression, which was detected by luminescence microscope (Leica, Berlin, Germany).

\section{Cell Growth Assay}

For the cell growth assay, $5 \times 10^{3}$ cells per well were seeded in triplicate into a 96-well plate with complete growth medium. Cells were then counted over five days using the MTT assay (Promega, Fitchburg, WI, USA) as described previously [12, 19-21].

\section{Migration and Invasion Assay}

We performed migration assays in 24-well plates (Transwell, Costar; $6.5 \mathrm{~mm}$ diameter and 3.0 $\mu \mathrm{M}$ ) (Cambridge, MA, USA) by adding $700 \mu \mathrm{l}$ fetal bovine serum to the lower chamber and $100 \mu \mathrm{l}$ of cell suspension $\left(10^{6} / \mathrm{ml}\right)$ to the upper chamber, then assessing cell numbers on the bottom (migr. Cells) and on the membrane (not migrated cells) $2 \mathrm{~h}$ later under an optical microscope. Matrigel invasion assays were performed with Biocoat Matrigel invasion chambers (Cambridge, MA, USA) as previously described [22]. Chambers were plated and assayed in the same manner. Well examinations were repeated in triplicate and the invaded/migrated cells were quantified per field of view and statistically analyzed.

\section{Statistical Analysis}

Data are presented as the mean \pm SEM from at least three independent experiments. The difference between groups were analyzed using two-tailed Student's $t$-test when only two groups were compared; the differences between groups were analyzed using ANOVA when three or more groups were compared. Mice survival rates and times were determined by Kaplan-Meier analysis. Statistical analyses were performed using SPSS software (Version 17.0) and P $<0.05$ was considered statistically significant.

\section{Results}

\section{USP14 Amplification in Various Cancers}

We found in a previous study that there are higher levels of USP14 in NSCLC tissues, which was associated with shorter survival time overall. Further, the overexpression of USP14 promotes tumor cell proliferation [12]. Clinical study and data analysis revealed that USP14 alterations, (especially amplification,) exist in a variety of cancers including bladder cancer, lung cancer (LC), breast cancer (BC), and pancreatic ductal adenocarcinoma (PDAC) (Fig. 1). We hypothesized, to this effect, that USP14 plays an oncogenic role in many cancers. 


\begin{tabular}{|c|c|c|}
\hline Cellular Physiology & Cell Physiol Biochem 2016;38:993-1002 & \\
\hline and Biochemistry & $\begin{array}{l}\text { DoI: 10.1159/000443051 } \\
\text { Published online: March 04, } 2016\end{array}$ & $\begin{array}{l}\text { O } 2016 \mathrm{~S} \text {. Karger AG, Basel } \\
\text { www.karger.com/cpb }\end{array}$ \\
\hline
\end{tabular}

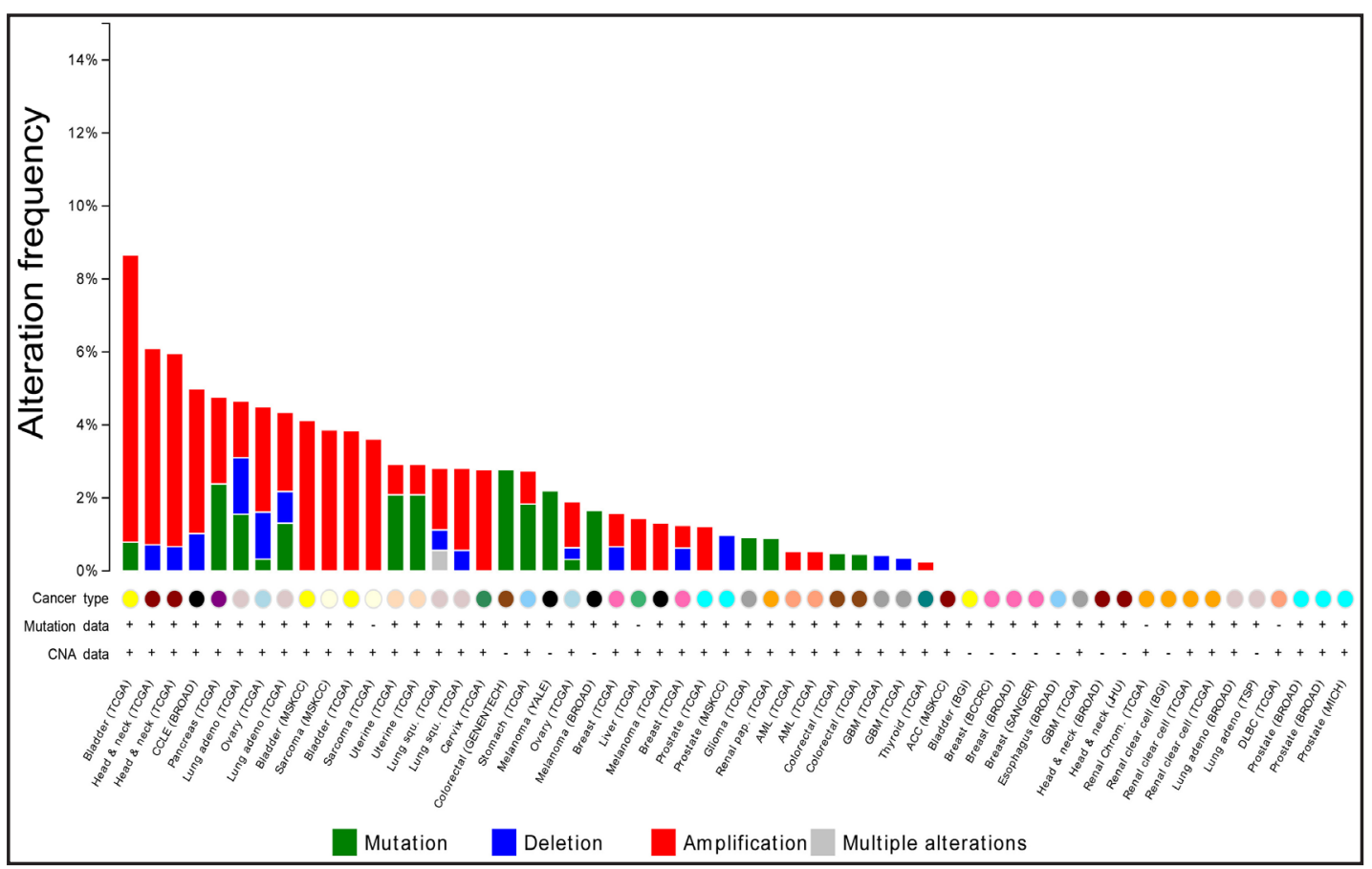

Fig. 1. Frequency of USP14 alteration in various types of cancer. Alterations of USP14 were visualized by cBioPortal for Cancer Genomics. Mutation, deletion, amplification, and other alterations are shown in different colors. The most frequent alteration of USP14 in different types of cancer is amplification. The "CAN" data is copy number alteration data.

USP14 Expression in Cancer Tissues

In order to evaluate the expression of USP14 in cancer tissues, we examined 45 LC tissues, $60 \mathrm{BC}$ tissues, and 37 PDAC tissues via immunohistochemistry (IHC) staining. We found that the USP14 protein levels in LC, BC, and PDAC tissues were higher compared to corresponding normal control tissue (Fig. 2A). First, we summarized the mean relative USP14 levels in all LC, BC, and PDAC tissues and arbitrarily defined the mean expression of USP14 in matched normal control samples as 100\% (Fig. 2B). Next, we analyzed the expression of USP14 in different types of cancer by exploring expression data in the Gene Expression Omnibus (GEO) database repository, a public gene expression resource. We found that in PDAC, breast cancer, and gastric cancer, the USP14 expression level is significantly higher in the tumor tissues than in the matched normal tissues; similarly, in the mammary tumorigenesis MMTVneu model, the level of USP14 is higher in tumors than in normal tissue. In melanoma, USP14 level in the metastatic site is higher than in the primary tumor site, suggesting that USP14 may promote tumor metastasis (Fig. 2C). We then assayed the levels of USP14 mRNA in various cancer cell lines, and found that USP14 is up-regulated in most of the cancer cell lines analyzed though the specific levels varied among lines (Fig. 2D). The more malignant cell lines, PANC1, MDA-231, U251, and DU145, show higher levels of USP14 expression, so we surmised that USP14 also plays a role in tumorigenesis.

USP14 Over-expression Effects and USP14 Low-expressing Cell Lines

The cancer cell lines H1299 and MCF7 show a relatively low expression of USP14 compared to other cell lines, thus, these cell lines were selected to further study the effects of USP14 overexpression by plasmid transfection (Fig. 3A). Cell proliferation analysis via an MTT assay $48 \mathrm{~h}$ post-transfection showed that USP14 up-regulation promotes H1299 and MCF7 cell proliferation (Fig. 3B). As anticipated, the relative colony number was increased by USP14 overexpression in both H1299 and MCF-7 (Fig. 3C) and, interestingly, the migration capacities of both cell lines were also increased by USP14 overexpression (Fig. 3D). 


\begin{tabular}{|c|c|c|}
\hline Cellular Physiology & Cell Physiol Biochem 2016;38:993-1002 & \\
\hline and Biochemistry & $\begin{array}{l}\text { DoI: 10.1159/000443051 } \\
\text { Published online: March 04, } 2016\end{array}$ & $\begin{array}{l}\text { O } 2016 \mathrm{~S} \text {. Karger AG, Basel } \\
\text { www.karger.com/cpb }\end{array}$ \\
\hline
\end{tabular}

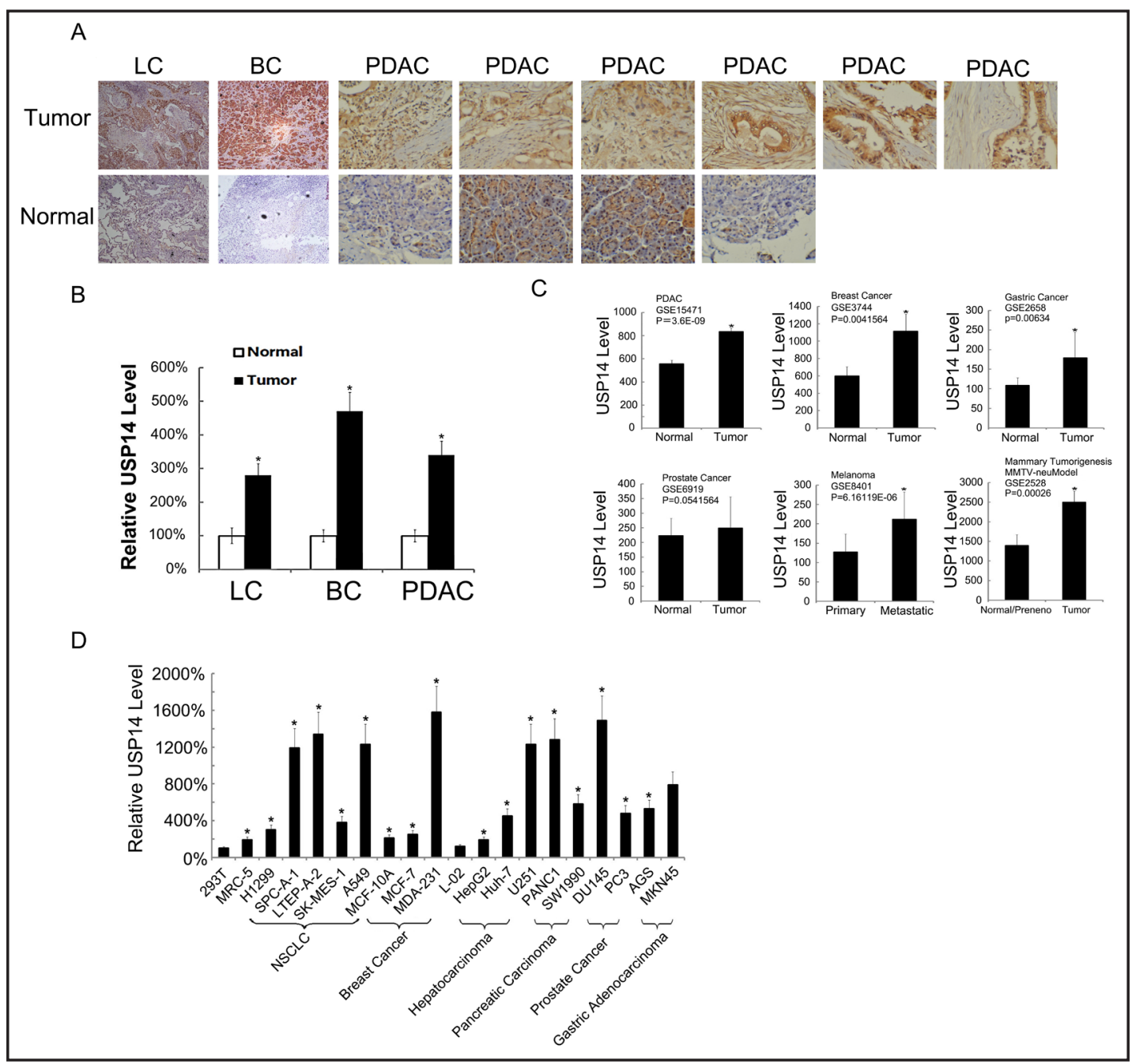

Fig. 2. Lung cancer, breast cancer, and pancreatic ductal adenocarcinoma tissues express higher levels of USP14. Forty-five lung cancer (LC) tissues, 60 breast cancer (BC) tissues, and 37 pancreatic ductal adenocarcinoma (PDAC) tissues were examined by immunohistochemistry (IHC) staining. Representative images of the IHC analysis of these three cancer types compared to their matched adjacent normal tissues are shown (A). The expression of USP14 as analyzed by IHC was digitized, (as well as its expression in normal tissue, which was arbitrarily defined as $100 \%$,) and data expressed as the mean \pm S.D. of USP14 expression in the three cancers (B). GEO data were analyzed to compare USP14 expression in tumors with matched normal tissues and the expression of USP14 in metastatic sites was compared to the primary site; the GSE number is shown in the graphs (C). NSCLC, breast cancer, hepatocarcinoma, pancreatic carcinoma, prostate cancer, and gastric adenocarcinoma were assayed by RT-PCR; data are the mean \pm SEM of three separate experiments (D), ${ }^{*} \mathrm{P}<0.05$.

\section{USP14 Down-regulation Suppresses Tumor Cell Function}

As shown in Fig. 2D, cell lines A549, MDA-231, Panc-1 and DU145 are USP14 highexpressing cells, so we selected them to investigate the effects of USP14 down-regulation transfection of shRNA lentiviral vectors. Analysis by real-time qRT-RCR showed both the USP14 shRNA-1 and the USP14 shRNA-2 lentiviral vectors down-regulated the level of USP14 in the four cell lines analyzed (Fig. 4A). The MTT cell proliferation assay conducted $48 \mathrm{~h}$ post transfection showed that transfection of USP14 shRNA-1 and USP14 shRNA-2 vectors suppress cells proliferation to a greater extent than control vector Src-shRNA (Fig. 4B). Additionally, transfection of the USP14 shRNA-1 vector decreased the colony number 


\begin{tabular}{|c|c|c|}
\hline Cellular Physiology & Cell Physiol Biochem 2016;38:993-1002 & \\
\hline and Biochemistry & $\begin{array}{l}\text { DOI: 10.1159/000443051 } \\
\text { Published online: March 04, } 2016 \\
\end{array}$ & $\begin{array}{l}\text { (0 2016 S. Karger AG, Basel } \\
\text { www.karger.com/cpb }\end{array}$ \\
\hline
\end{tabular}

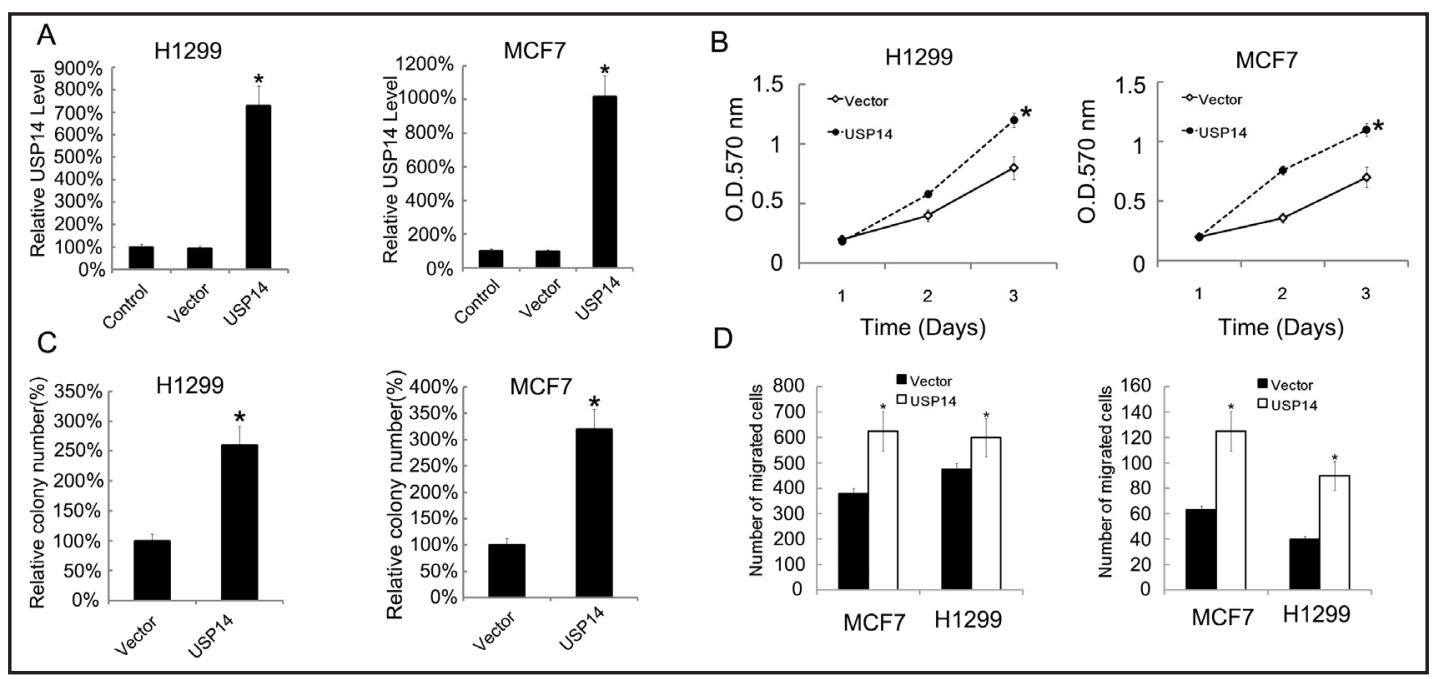

Fig. 3. Overexpression of USP14 promotes H1299 and MCF-7 cell proliferation and migration. The relative level of USP14 in H1299 and MCF-7 was assayed by qRT-PCR. Data are the mean \pm SEM of three separate experiments. Transfection of the empty vector and blank transfection were used as controls, and data in the blank control was arbitrarily defined as 100\% (A). H1299 and MCF7 were transfected with the USP14 overexpression plasmid at a density of $5 \times 10^{5}$ cells/well, and MTT assays performed 24h later; data are mean \pm SEM of three separate experiments (B). After transfection, the colony number of H1299 and MCF7 were counted, (the colony number of the control was arbitrarily defined as $100 \%$,) and data expressed as the mean \pm SEM of three separate experiments (C). In the cell migration assay, H1299 and MCF7 migrated cells were collected after $2 \mathrm{~h}$; data are the mean \pm SEM of three separate experiments (D), $* \mathrm{P}<0.05$.

of the four cell lines analyzed (Fig. 4C). Apoptosis analysis by FACS revealed that the downregulation of USP14 results in increased apoptosis rate of A549, MDA-231, Panc-1, and DU145 cell lines (Fig. 4D). Furthermore, migration (Fig. 4E) and invasion (Fig. 4F), assayed to examined USP14 in terms of key features of malignant tumor cells, both decreased due to USP14 down-regulation in the A549 and MDA-231 cell lines.

\section{In Vivo Effect of USP14 Down-regulation}

To evaluate in the vivo effect of USP14 down-regulation, we investigated whether the levels of USP14 expression were associated with overall survival of nude mice inoculated with A549 cells transfected with USP14 shRNA or control shRNA vector. The expression of USP14 in A549 cells was first down-regulated by shRNA transfection, then transfected A549 were inoculated into the nude mice subcutaneously. We found that measureable tumors first emerged in the control mice, and that mice treated with USP14 shRNAs showed lowervolume emerging tumors at the same time point (Fig. 5A). We also measured the survival times of these mice during a period of 160-days post-transfection, and found that the downregulation of USP14 effectively protected the mice, as there were more deceased mice in the control group as their tumors progressed. The Kaplan-Meier curves indicated that mice treated with cells in which USP14 was down-regulated had a significantly lengthier overall survival time than those treated with control cells (Fig. 5B).

\section{Discussion}

In this study, under guidance by the TCGA project, we investigated the role of USP14 in various types of cancer and found that USP14 plays an important role in tumorigenesis. The TCGA has applied promising emerging technologies to the analysis of specific tumor types, and its disease-specific approach has revealed novel oncogenic drivers and genes contributing to functional changes [23-25], established definitions of molecular subtypes 


\begin{tabular}{|c|c|c|}
\hline Cellular Physiology & Cell Physiol Biochem 2016;38:993-1002 & \\
\hline and Biochemistry & $\begin{array}{l}\text { DoI: 10.1159/000443051 } \\
\text { Published online: March 04, } 2016\end{array}$ & $\begin{array}{l}\text { O } 2016 \mathrm{~S} \text {. Karger AG, Basel } \\
\text { www.karger.com/cpb }\end{array}$ \\
\hline
\end{tabular}

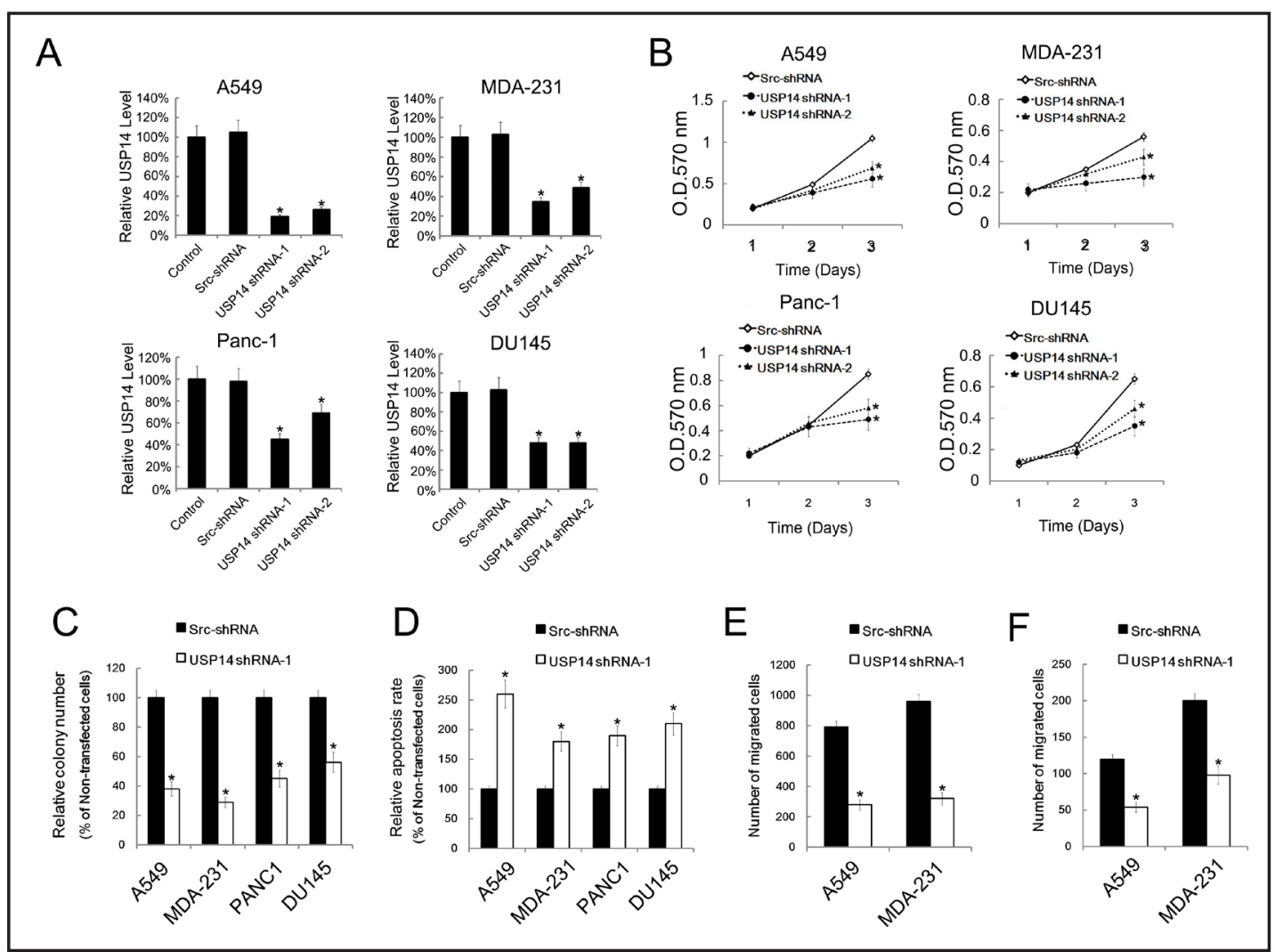

Fig. 4. Down-regulation of USP14 reduces tumor cell proliferation and induces cell apoptosis. Cancer cell lines A549, MDA-231, Panc-1 and DU145 were transfected with shRNA lentiviruses vectors. The USP14 levels in the cells were assayed by qRT-PCR $48 \mathrm{~h}$ post-transfection, and transfection of an empty plasmid was used as a blank control, the value of which was arbitrarily defined as 100\% (A). A549, MDA-231, Panc-1, and DU145 were infected with USP14 shRNA lentiviruses at density of $5 \times 10^{5}$ cells/well; MTT assay was performed $24 \mathrm{~h}$ later and OD values recorded. Data are the mean \pm SEM of three separate experiments (B). After USP14 shRNA-1 infection, the colony numbers of A549, MDA-231, Panc-1, and DU145 were counted and the colony numbers of the control arbitrarily defined as 1 ; data are the mean \pm SEM of three separate experiments (C). After USP14 shRNA-1 lentivirus infection, the apoptosis cells were stained (Annexin V) and counted by FACS, and the percentage of apoptosis cells in the control arbitrarily defined as 100\%; data are the mean \pm SEM of three separate experiments (D). The migrated cells of A549 and MDA-23 after $3 \mathrm{~h}$ were also collected and counted, and data expressed as the mean \pm SEM of three separate experiments (E). The migrated cells of A549 and MDA-23 were also collected and counted, and data expressed as the mean \pm SEM of three separate experiments (F), ${ }^{*} \mathrm{P}<0.05$.

[26-32], and identified new biomarkers on the basis of genomic, transcriptomic, proteomic, and epigenomic alterations. In this study, we found that USP14 amplification causes major alteration in various types of cancer (Fig. 1), suggesting that USP14 is involved in many different types of cancer. Gene Expression Omnibus (GEO) analysis also indicated a higher level of USP14 is expressed in a variety of cancers, with prostate cancer as a notable exception (Fig. 2C); this observation is consistent with the fact that USP14 deletion is a major USP14 alteration inherent to prostate cancer (Fig. 1). We also found that in the mammary tumorigenesis MMTV-neu model, USP14 level in tumors is also higher than in normal tissue.

This study was a preliminary effort to begin to understand the functional relevance of USP14 in cancer. In a clinically relevant experiment, we did successfully identify USP14 overexpression in several different types of cancer, however, changes in USP14 level among different clinical cancers and cancer cell lines was highly variable. It is worth noting that USP14 amplification in liver cancer and its expression in the hepatocarcinoma cell line are 


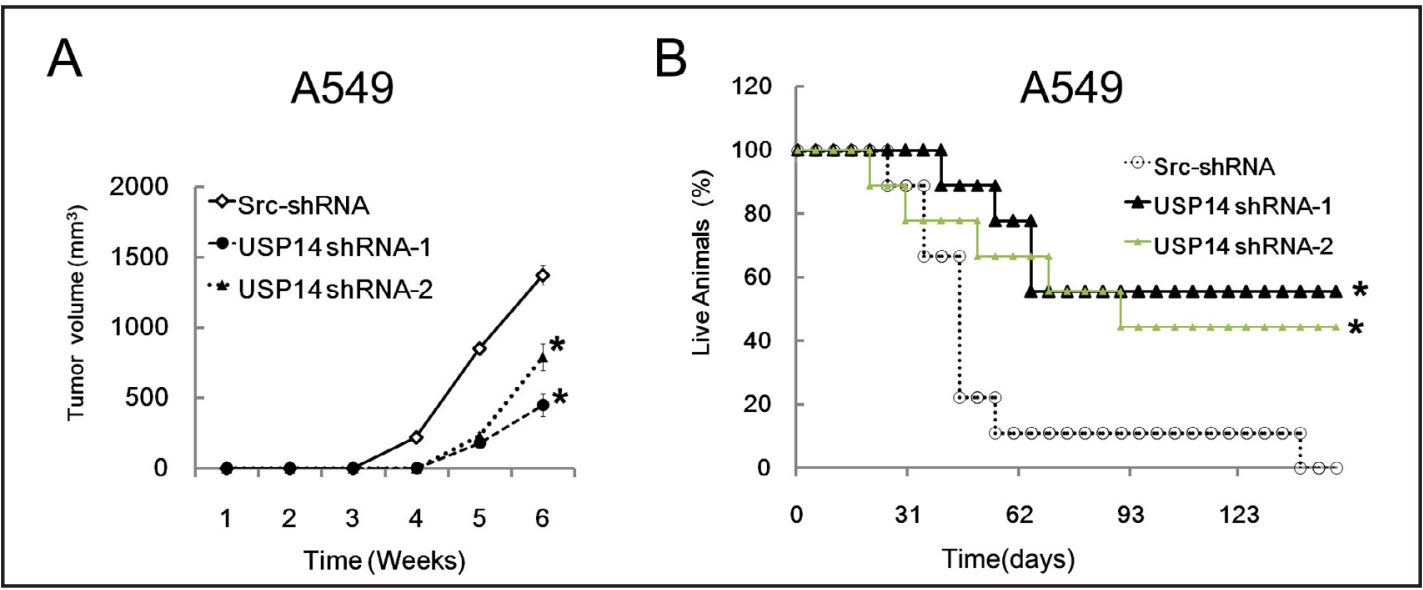

Fig. 5. USP14 down-regulation reduces tumor growth in vivo and favors mouse survival. A549 cells were pretreated with USP14 shRNA-1 lentiviruses and injected into nude mice subcutaneously, then tumor volumes counted every week (A). The Kaplan-Meier plot of mice survival after A549 inoculation was drawn according to USP14 shRNA-1 lentivirus infection status (B), ${ }^{*} \mathrm{P}<0.05$.

relatively low, suggesting that USP14 might not be involved in liver cancer tumorigenesis - this may, in fact, hint toward the mechanism involved in USP14's effects on cancer. In a previous study, we found that $\beta$-catenin protein levels sharply decrease in conjunction with USP14 silencing in A549 cells [12], researchers have likewise found that $\beta$-catenin, a key member in the Wnt pathway that promotes proliferation in various tumors [33-38], is controlled through ubiquitination [39-41]. Given this information, SOX1, a developmental gene, may function as a tumor suppressor by interfering with Wnt/ $\beta$-catenin signaling in the development of hepatocellular carcinoma. Together, these observations support the hypothesis that low expression of USP14 in hepatocellular carcinoma is correlated with SOX1 function.

As discussed above, we found that USP14 exhibited oncogenic roles in various types of cancer. It is thus possible that USP14 inhibition suppresses tumor proliferation. A smallmolecule inhibitor of USP14 has been developed and shown to enhance proteasome activity [2], likely because USP14 regulates proteasomal ATPases [42]. We hope that USP14 inhibition will show therapeutic effects, which we plan to investigate in future studies.

In conclusion, our data proved the role of USP14 in tumorigenesis and suggests a potential molecular therapy target for future cancer treatment development.

\section{Acknowledgements}

This work was supported by grants from the National Natural Science Foundation of China (Grants No. 81201850).

\section{Disclosure Statement}

The authors have declared that no competing interests exist.

\section{References}

1 Sowa ME, Bennett EJ, Gygi SP, Harper JW: Defining the human deubiquitinating enzyme interaction landscape. Cell 2009;138:389-403.

2 Lee BH, Lee MJ, Park S, Oh DC, Elsasser S, Chen PC, Gartner C, Dimova N, Hanna J, Gygi SP, Wilson SM, King RW, Finley D: Enhancement of proteasome activity by a small-molecule inhibitor of USP14. Nature 2010;467:179-184. 


\section{Cellular Physiology Cell Physiol Biochem 2016;38:993-1002 \begin{tabular}{ll|l} 
and Biochemistry & $\begin{array}{l}\text { DOI: 10.1159/000443051 } \\
\text { Published online: March 04, } 2016\end{array}$ & $\begin{array}{l}\text { C 2016 S. Karger AG, Basel } \\
\text { www.karger.com/cpb }\end{array}$
\end{tabular} \\ Zhu et al.: USP14 as Oncogene}

3 Anderson C, Crimmins S, Wilson JA, Korbel GA, Ploegh HL, Wilson SM: Loss of Usp14 results in reduced levels of ubiquitin in ataxia mice. J Neurochem 2005;95:724-731.

$4 \quad$ Nag DK, Finley D: A small-molecule inhibitor of deubiquitinating enzyme USP14 inhibits Dengue virus replication. Virus Res 2012;165:103-106.

5 Peth A, Besche HC, Goldberg AL: Ubiquitinated proteins activate the proteasome by binding to Usp14/ Ubp6, which causes 20S gate opening. Mol Cell 2009;36:794-804.

6 Mines MA, Goodwin JS, Limbird LE, Cui FF, Fan GH: Deubiquitination of CXCR4 by USP14 is critical for both CXCL12-induced CXCR4 degradation and chemotaxis but not ERK ativation. J Biol Chem 2009;284:57425752.

7 Wilson SM, Bhattacharyya B, Rachel RA, Coppola V, Tessarollo L, Householder DB, Fletcher CF, Miller RJ, Copeland NG, Jenkins NA: Synaptic defects in ataxia mice result from a mutation in Usp14, encoding a ubiquitin-specific protease. Nat Genet 2002;32:420-425.

8 Borodovsky A, Kessler BM, Casagrande R, Overkleeft HS, Wilkinson KD, Ploegh HL: A novel active sitedirected probe specific for deubiquitylating enzymes reveals proteasome association of USP14. EMBO J 2001;20:5187-5196.

9 Wu N, Zhang C, Bai C, Han YP, Li Q: MiR-4782-3p inhibited non-small cell lung cancer growth via USP14. Cell Physiol Biochem 2014;33:457-467.

10 Ao N, Liu Y, Feng H, Bian X, Li Z, Gu B, Zhao X, Liu Y: Ubiquitin-specific peptidase USP22 negatively regulates the STAT signaling pathway by deubiquitinating SIRT1. Cell Physiol Biochem 2014;33:1863-1875.

11 Xu Y, Lu S: Metformin inhibits esophagus cancer proliferation through upregulation of USP7. Cell Physiol Biochem 2013;32:1178-1186.

12 Wu N, Liu C, Bai C, Han YP, Cho WC, Li Q: Over-Expression of Deubiquitinating Enzyme USP14 in Lung Adenocarcinoma Promotes Proliferation through the Accumulation of beta-Catenin. Int J Mol Sci 2013;14:10749-10760.

13 Weinstein JN, Collisson EA, Mills GB, Shaw KR, Ozenberger BA, Ellrott K, Shmulevich I, Sander C, Stuart JM: The Cancer Genome Atlas Pan-Cancer analysis project. Nat Genet 2013;45:1113-1120.

14 Cerami E, Gao J, Dogrusoz U, Gross BE, Sumer SO, Aksoy BA, Jacobsen A, Byrne CJ, Heuer ML, Larsson E, Antipin Y, Reva B, Goldberg AP, Sander C, Schultz N: The cBio cancer genomics portal: an open platform for exploring multidimensional cancer genomics data. Cancer Discov 2012;2:401-404.

15 Gao J, Aksoy BA, Dogrusoz U, Dresdner G, Gross B, Sumer SO, Sun Y, Jacobsen A, Sinha R, Larsson E, Cerami E, Sander C, Schultz N: Integrative analysis of complex cancer genomics and clinical profiles using the cBioPortal. Sci Signal 2013;6:pl1.

16 Chen C, Ridzon DA, Broomer AJ, Zhou Z, Lee DH, Nguyen JT, Barbisin M, Xu NL, Mahuvakar VR, Andersen MR, Lao KQ Livak KJ, Guegler KJ: Real-time quantification of microRNAs by stem-loop RT-PCR. Nucleic Acids Res 2005;33:e179.

17 Hofig I, Atkinson MJ, Mall S, Krackhardt AM, Thirion C, Anastasov N: Poloxamer synperonic F108 improves cellular transduction with lentiviral vectors. J Gene Med 2012;14:549-560.

18 Wu DT, Seita Y, Zhang X, Lu CW, Roth MJ: Antibody-directed lentiviral gene transduction for live-cell monitoring and selection of human iPS and hES cells. PLoS One 2012; 7:e34778.

19 Liu C, Li B, Cheng Y, Lin J, Hao J, Zhang S, Mitchel RE, Sun D, Ni J, Zhao L, Gao F, Cai J: MiR-21 plays an important role in radiation induced carcinogenesis in BALB/c mice by directly targeting the tumor suppressor gene Big-h3. Int J Biol Sci 2011;7:347-363.

20 Liu C, Gao F, Li B, Mitchel RE, Liu X, Lin J, Zhao L, Cai J: TLR4 knockout protects mice from radiationinduced thymic lymphoma by downregulation of IL6 and miR-21. Leukemia 2011;25:1516-1519.

21 Liu C, Zhou C, Gao F, Cai S, Zhang C, Zhao L, Zhao F, Cao F, Lin J, Yang Y, Ni J, Jia J, Wu W, Zhou L, Cui J, Zhang W, Li B, Cai J: MiR-34a in age and tissue related radio-sensitivity and serum miR-34a as a novel indicator of radiation injury. Int J Biol Sci 2011;7:221-233.

22 Valster A, Tran NL, Nakada M, Berens ME, Chan AY, Symons M: Cell migration and invasion assays. Methods 2005;37:208-215.

23 Tomlins SA, Rhodes DR, Perner S, Dhanasekaran SM, Mehra R, Sun XW, Varambally S, Cao X, Tchinda J, Kuefer R, Lee C, Montie JE, Shah RB, Pienta KJ, Rubin MA, Chinnaiyan AM: Recurrent fusion of TMPRSS2 and ETS transcription factor genes in prostate cancer. Science 2005;310:644-648. 


\section{Cellular Physiology Cell Physiol Biochem 2016;38:993-1002 \begin{tabular}{l|l|l}
\hline DOI: 10.1159/000443051 & (C) 2016 S. Karger AG, Basel
\end{tabular}

24 Davies H, Bignell GR, Cox C, Stephens P, Edkins S, Clegg S, Teague J, Woffendin H, Garnett MJ, Bottomley W, Davis N, Dicks E, Ewing R, Floyd Y, Gray K, Hall S, Hawes R, Hughes J, Kosmidou V, Menzies A, Mould C, Parker A, Stevens C, Watt S, Hooper S, Wilson R, Jayatilake H, Gusterson BA, Cooper C, Shipley J, Hargrave D, Pritchard-Jones K, Maitland N, Chenevix-Trench G, Riggins GJ, Bigner DD, Palmieri G, Cossu A, Flanagan A, Nicholson A, Ho JW, Leung SY, Yuen ST, Weber BL, Seigler HF, Darrow TL, Paterson H, Marais R, Marshall CJ, Wooster R, Stratton MR, Futreal PA: Mutations of the BRAF gene in human cancer. Nature 2002;417:949954.

25 Mardis ER, Ding L, Dooling DJ, Larson DE, McLellan MD, Chen K, Koboldt DC, Fulton RS, Delehaunty KD, McGrath SD, Fulton LA, Locke DP, Magrini VJ, Abbott RM, Vickery TL, Reed JS, Robinson JS, Wylie T, Smith SM, Carmichael L, Eldred JM, Harris CC, Walker J, Peck JB, Du F, Dukes AF, Sanderson GE, et al.: Recurring mutations found by sequencing an acute myeloid leukemia genome. N Engl J Med 2009;361:1058-1066.

26 Comprehensive molecular characterization of clear cell renal cell carcinoma. Nature 2013;499:43-49.

27 Kandoth C, Schultz N, Cherniack AD, Akbani R, Liu Y, Shen H, Robertson AG, Pashtan I, Shen R, Benz CC, Yau C, Laird PW, Ding L, Zhang W, Mills GB, Kucherlapati R, Mardis ER, Levine DA: Integrated genomic characterization of endometrial carcinoma. Nature 2013;497:67-73.

28 Cancer Genome Atlas Network: Comprehensive molecular portraits of human breast tumours. Nature 2012;490:61-70.

29 Cancer Genome Atlas Research Network: Comprehensive genomic characterization of squamous cell lung cancers. Nature 2012;489:519-525.

30 Cancer Genome Atlas Network: Comprehensive molecular characterization of human colon and rectal cancer. Nature 2012;487:330-337.

31 Cancer Genome Atlas Research Network: Integrated genomic analyses of ovarian carcinoma. Nature 2011;474:609-615.

32 Cancer Genome Atlas Research Network: Comprehensive genomic characterization defines human glioblastoma genes and core pathways. Nature 2008;455:1061-1068.

33 Yang L, Chen Y, Cui T, Knosel T, Zhang Q, Albring KF, Huber O, Petersen I: Desmoplakin acts as a tumor suppressor by inhibition of the Wnt/beta-catenin signaling pathway in human lung cancer. Carcinogenesis 2012;33:1863-1870.

34 Tsao CM, Yan MD, Shih YL, Yu PN, Kuo CC, Lin WC, Li HJ, Lin YW: SOX1 functions as a tumor suppressor by antagonizing the WNT/beta-catenin signaling pathway in hepatocellular carcinoma. Hepatology 2012;56:2277-2287.

35 Subbaiah VK, Narayan N, Massimi P, Banks L: Regulation of the DLG tumor suppressor by beta-catenin. Int J Cancer 2012;131:2223-2233.

36 Yoshioka S, King ML, Ran S, Okuda H, MacLean JA, 2nd, McAsey ME, Sugino N, Brard L, Watabe K, Hayashi K: WNT7A regulates tumor growth and progression in ovarian cancer through the WNT/beta-catenin pathway. Mol Cancer Res 2012;10:469-482.

37 Shu XS, Geng H, Li L, Ying J, Ma C, Wang Y, Poon FF, Wang X, Ying Y, Yeo W, Srivastava G, Tsao SW, Yu J, Sung JJ, Huang S, Chan AT, Tao Q: The epigenetic modifier PRDM5 functions as a tumor suppressor through modulating WNT/beta-catenin signaling and is frequently silenced in multiple tumors. PLoS One 2011;6:e27346.

38 Wang EY, Yeh SH, Tsai TF, Huang HP, Jeng YM, Lin WH, Chen WC, Yeh KH, Chen PJ, Chen DS: Depletion of beta-catenin from mature hepatocytes of mice promotes expansion of hepatic progenitor cells and tumor development. Proc Natl Acad Sci USA 2011;108:18384-18389.

39 Sadot E, Simcha I, Iwai K, Ciechanover A, Geiger B, Ben-Ze'ev A: Differential interaction of plakoglobin and beta-catenin with the ubiquitin-proteasome system. Oncogene 2000;19:1992-2001.

40 Tran H, Polakis P: Reversible modification of adenomatous polyposis coli (APC) with K63-linked polyubiquitin regulates the assembly and activity of the beta-catenin destruction complex. J Biol Chem 2012;287:28552-28563.

41 Jeong WJ, Yoon J, Park JC, Lee SH, Kaduwal S, Kim H, Yoon JB, Choi KY: Ras stabilization through aberrant activation of Wnt/beta-catenin signaling promotes intestinal tumorigenesis. Sci Signal 2012;5:ra30.

42 Peth A, Kukushkin N, Bosse M, Goldberg AL: Ubiquitinated proteins activate the proteasomal ATPases by binding to Usp14 or Uch37 homologs. J Biol Chem 2013;288:7781-7790. 